\title{
A Coat of Many Doctrinal Controversies: An X-Ray of Nigerian Christian Spirituality
}

\author{
Nmah, Patrick \\ Enoch-Department of Religion and Human Relations, Nnamdi Azikiwe University, Awka-Nigeria \\ Email: patricknmah@yahoo.com
}

\author{
Doi:10.5901/mjss.2015.v6n3s2p367
}

\section{Abstract}

A coat of many doctrinal controversies: an x-ray of Nigerian Christian spirituality appraised some salient doctrinal differences among Christian denominations in Nigeria, which often hampered unity among the competing denominations in the 21st century. Findings showed that there was lack of national unity among the Christian churches. Factors that conditioned the doctrinal controversy included sacraments, sola scriptura, sola fide, sola gracia, indulgence, perpetual virginity of Mary, purgatory, infallibility of the Pope, women ordination, infant baptism, homosexuality among others. The work recommended that oneness of Christians in Nigeria should be Christocentric, unity in diversity, and sola scriptura. Methods of approach are historical, comparative and descriptive methods.

\section{Introduction}

In Nigeria, according to Enwerem (1995), there was at the outset a lack of national unity among the Christian churches in 1960s, although there was some interaction among them. There were three blocs of Christianity namely the Christian Council of Nigeria (CCN) in the South, the Christian Movement in the North and the United Roman Catholicism Episcopal Conference each of which meets at least once a year and spoke with one voice. 1980s saw the emergence of Pentecostal Fellowship of Nigeria (PFN). Early Church history bears evidence of disagreement in the church and attempts made to keep the church one. To Ekpunobi (2001), some of these disagreements and misrepresentations arose out of the natural inquisitive and probing impulse of the human mind, which is not distinct from the contemporary Nigerian Christian experience. Doctrine divides service unites, but selfless service to humanity is essential oneness of the church. When we serve in different fields, is it education, health, or other social services, we are closer than we think. Denominations are not permanent divisions. Ecumenical dialogue is an answer to Nigerian religious divides. The main objectives of this study is to discuss the effects of different Christian doctrinal beliefs and practices in Nigeria and how it has created unnecessary rivalry, hatred, envy, spiritual barrenness and so on among Nigerian Christians and to offer suggestions on how to cushion the effects of the doctrinal challenges. The respondents are Nigerian Christians.

\section{Conceptual Framework}

Denomination is derived from the English word denominate which means, "To give a name to; to designate to style" (Ekpunobi, 2001). Denomination is the noun that means, "Act of naming, a title, a class, and a religious sect" A denomination is an independent and distinct religious group different from other congregations.

Denominations opt out of the mainstream because of their desire to emphasize one doctrine or the other. Some grew out of discontent with the teaching and organization of the Orthodox Church. They usually set up their own system of organization and administration. They take names that will distinguish them from others.

Denomination can be defined as the religious or sect that rejects the social environment, norms or virtues in which it operates or exists (Quarcoopome, 1985). It is a religious conflict society or group which has arisen in opposition to an institutionalized church (Agunwa, 2008). Denomination can also be seen as exclusive religious group or sect politically motivated because of social economic and emotional reasons. It is a kind of protest against established churches. Denomination refers at time to a congregation of Christians in a region who have united themselves to work and worship together. They have a pattern of organizational work that they are to do, and funds they are to do this work. In the Bible, the Christians were not just members of the universal body of all sacred people, but they associated themselves into local churches or denominations. It is a group of congregation that is joined together under some governing body that effectively serves to distinguish and divide them from other congregations. Martin (1993) defines denominationalism as 
an act of denomination; name designation especially a general name for a class of things, a religious body comprising a number of congregations. The definitions given to denomination by Quarcoopome and Agunwa shall form our working definition.

Doctrine in the Old Testament occurs chiefly as a translation of leqah, meaning 'what is received' (Dt. 32:2; Job 11:4; Pr. 4:2; Is. 29:24) (Douglas, 1980). The idea of a body of revealed teaching is chiefly expressed by tôrā, which occurs 216 times and is rendered as "law". In the New Testament two words are used namely Didaskalia and Didache which mean both the act and content of teaching. The latter occurs of the teaching of Jesus (Mt. 7:28) which he claimed to be divine (Jn. 7:16-17). After Pentecost Christian doctrine began to be formulated (Acts 2:42) as the instruction given to those who had responded to the Kerygma (Rom. 6:17). According to Boer (1976), at the end of the first century and during the first half of the second century, a significant group of Christian writings appeared in the early church. Their authors are known as the Apostolic Fathers. They were given this name because the church regarded them as disciples of the apostles. The fathers in question, together with the place and date of their writing, are Clement of Rome (AD 95), Ignatius of Antioch (110-117), Polycarp of Smyrna (117-118), Barnabas, probably of Alexandria (130), Hermas of Rome (100), and Papias of Hierapolis in Phrygia (140). Included in the writings of these fathers is a handbook of Christian instruction entitled, The Teaching of the Twelve Apostles, better known as the Didache (or teaching), perhaps written in Syria about AD 100. The definition that designated doctrine as what is received or a body of revealed teaching shall constitute our working definition.

\section{A Coat of Many Doctrinal Controversies}

The Church of the West prior to the reformation disgusted at the authority of the Pope as infallible; the merit of good work; indulgence; immaculate conception of Virgin Mary; veneration of Mary and the saints; transubstantiation; purgatory; prayers for the dead; confession to a priest; celibacy for the priest and among others. This is followed by the reformation carried out by Lutheranism, Zwinglianism, Calvinism, Aminianism and Elizabethan religious settlement mainly on the scripture, salvation, sacrament and rituals in 16th century then the Anglican via-media in the 19th century. The place of Anglican via-media in the contemporary challenges namely women ordination and episcopacy, homosexuality and lesbianism, the problem of scriptural interpretation and the challenge of culture.

The infallibility of the Pope entails "inability to err in teaching revealed truth" (Cross and Livingstone, 1997, p. 831). It means immunity from error or inability of making fundamental mistakes in religious matters. Standford (2009) observed that though papal infallibility was only set in stone in 1870, the idea had been part of church history and debate as far back as 519AD when the notion of the Bishop of Rome as the preserver of apostolic truth was set out in the Formula of Hormisdas. In 1075, Pope Gregory VII in his Dictatus Papae (The Pope's memorandum) puts it more bluntly. He sets out 27 propositions about the powers of the office of Bishops of Rome. Henderson (1910) cited Gregory VII: Dictatus Papae of 1090 thus: that the Roman Church was founded by God alone, that the Roman Pontiff alone can with right be called universal, that he alone can depose or reinstate bishops and so on.

On the concept of the merit of good work, this means a good work to which recompense is attached. But God owes man no reward for God is a debtor to no man. On the doctrine of indulgence, Matthew (2005) citing Pope Paul VI, said that an indulgence is a remission before God of the temporal punishment due to sins whose guilt has already been forgiven. In essence, without Jesus Christ; there would be no forgiveness and no salvation. The Church by means of indulgence remits this temporary punishment by applying to man the superabundant merit of Jesus Christ, of the blessed virgin and of the saints, which constitute what is known as the treasure of the church.

Historically, Shelley (2008) maintains that the sale of indulgence was introduced during the crusades as a source of papal income whereby an exchange for meritorious work is made either by contribution to a cause or a pilgrimage to a shrine. Pope alone that has the power to grant indulgence in the whole church, and the bishop in his own diocese, according to the faculty given him by the pope. By granting indulgences the church intends to aid man's incapacity to expiate all the temporal punishment in this world, by enabling him to obtain by means of works of piety and Christian charity that which in the first ages Christians gained by the rigour of canonical penance. Therefore, to acquire a plenary indulgence it is necessary to perform the work to which the indulgence is attached and to fulfill the following three conditions: sacramental confession, eucharistic communion, and prayer for the intention of the sovereign pontiff.

On immaculate conception of virgin Mary, it is evidently clear that the veneration of virgin Mary as mother of Christ has been an important part of Catholic theology while the devotion and honour paid to her is the highest the church has ever done to a creature of God. To Miravalle (1993), the virgin Mary, who at the message of the angel received the word of God in her heart and in her body and gave life to the world, is acknowledged and honour as being truly the mother of God and of the redeemer. These words of the Second Vatican Council echoed the Council of Ephesus wherein 431 AD, 
this early ecumenical council defined the first Marian doctrine, which the motherhood of God, "Theotokos," proclaims that Mary is truly the mother of God the son made man: "The Holy virgin is the mother of God since according to the flesh she brought forth the word of God made flesh" (p. xiii). A few centuries later, the living and praying Church, pondering the scriptural revelation of Mary's virginity, defined the second Marian doctrine, the Perpetual Virginity of Mary. At the Lateran Council in 649, Pope Martin I proclaimed the three-fold nature of the virginity of Mary: "She conceived without seed, of the Holy Spirit and without injury brought him forth and after his birth preserved her virginity inviolate" ( $p$. xiii). The third Marian doctrine came to its most complete illumination by the Church more than a thousand years later. "The Most Holy Virgin Mary was, in the first moment of her conception, by a unique gift of grace and privilege of Almighty God, in view of the merits of Jesus Christ, the Redeemer of mankind, preserved free from all stain of original sin" (p. xiv).

Fundamental beliefs and practices of different strands of the church of reformation again constitute also in themselves part of the doctrinal controversy. This includes the concept of sola scriptura (scripture alone as the yardstick of faith), the sola fide (faith only), the sola gracia (only grace as a means of salvation), the solus Christus or the sola Christo (the teaching that Christ is only mediator-the only pre-eminence High Priest between God and man) and soli Deo gloria (The glory God only). Elizabethan religious settlement, a solution to the 16th and 17th century religious arises in England also compounded the problem of doctrinal controversy. Her via-media approach widened the religious crack visà-vis the ordination of women, women consecrated as bishops, the acceptance of homosexual deepened also the disunity.

It would seem that the autonomy of denominations or dioceses is attractive to people as it is economically, politically, socially and self-identity rewarding. Or do Roman Catholic Church, Eastern Orthodox Catholic Church, AngloCatholic Church, Methodist Church, Qua Iboe Church, Presbyterian Church, Evangelical Church of West Africa (ECWA), Assemblies of God Mission, Grace of God Mission, Mountain of Fire and Miracles Ministries, Church of God Mission, Deeper Life Bible Church Mission among others will prefer to remain separate, because of the mundane considerations? Kalu (1978) opined that denominationalism is a subversion of the Church of Christ, a distortion of the kingdom of God.

Denominations are not bad in themselves because they are only branches of the one true church. The church is referred to as the body of Christ. It is said that, "Doctrine divides, service unites" (Ekpunobi, 2001, p. 7). Selfless service to humanity is essential oneness of the church. When we serve in different fields, be it education, health, economy or social services, we are closer than we think.

\section{An X-Ray of Nigerian Christian Spirituality in the Face of Doctrinal Controversy}

The doctrinal controversy has alienated the majority of Christian believers by promising equality in heaven while supporting a highly stratified and economically exploitive life here on earth. By this type of litany of doctrinal bureaucratic sins, millions of the nation's Christian citizens are denied the greater part of what by the very lowest standards are today called necessities of life. Millions are denied education, employment, recreation, fellowship and the opportunity to better their lot and the lot of their children on the basis of denominational doctrinal issues. It is this "dichotomization" of reality, the truth, and that distorted interpretation of the scriptures and of the Christian precept of forgiveness, which has impoverished the Christian theology of salvation.

It is the enormous artificial gap created by "man" between "here and now" and the "beyond" that this research work seeks to bridge. This does not run any risk of "reducing Christianity to a mere instrument for social, economic and political advancement," because Christianity, guided by respective denominational ethics, beliefs and practices, will surely degenerate into mere frivolous antics and spiritual caricature.

Within African context, cultural syncretism in worship such as dancing, drumming and clapping, use of symbols, ritual avoidances, festivals and rites, condemned by mainline churches are reinterpreted or given new mandate through the scriptures. The ethos, the type of morality advocated by the West is often legalistic and rigoristic such as Sabbathkeeping, observance of hours of prayer, avoidance of alcohol and tobacco, practice of polygamy usually tolerated rather than encouraged, ancestral cult, and earth-goddess and so on. Some of these are derived from biblical liberalism or traditional codes of morality. These beliefs and practices could be harnessed for proper Nigerian Christian Fellowship. This should be done in order to unite God's people in a land of lost unity, to bring about a real change in the present situation in spite of surrounding doctrinal controversies.

We Africans or Nigerians perse feel insecure in many ways-corruptions, health, economic, terrorism, covert or overt religious extremism, political, social, cultural, religious and the like. We have to confront the fears of charms, witchcraft, and evil powers and their influences. But the established churches are institutions devoid of spiritual power to repel these evil powers. The African Initiated Churches (AICS) did not come out of African culture, but were formed to give relevance spiritual power to individuals, and for the particular benefits it offers, especially healing and revelation 
devoid of mission churches doctrinal controversy.

\section{The Way Forward}

The oneness of Christians in Nigeria is primarily Christocentric. It is heavenward. As Christians look up to the Lord Jesus Christ, they are drawn closer together. There is the need for the various denominations to understand that in the spirit of unity in diversity that extremism, exclusivism of any kind is not allowed. The cross of Christ draws Christians together irrespective of denominationalism, ethnicism, creed or class differences. The cross stands for reconciliation between God and us (2 Cor. 5:19). It is "through the blood of his cross, his precious blood, the blood of expiation, that God has made peace, in reconciling all things to himself" (Col. 1:20ff). Christianity as a product of the cross entails that no Christian can do what he likes, but he must do what Jesus Christ likes. The church is to be one (Nmah 2012). The prayer of the great high priest is that the church should be one (Jn. 17:20-23). Jesus talked about other sheep which were physically separated and which must be brought to one fold (Jn. 10:16).

Early Church history bears evidence of disagreement in the church and attempts made to keep the church one. According to Expunobi (2001), some of these disagreements and misrepresentations arose out of the natural inquisitive and probing impulse of the human mind. Denominations are not permanent divisions. History tells us that a vibrant and populous denomination can fade away. They are fluid in nature as members can and do switch their affiliation at will.

There is a growing concern for co-operation among the churches. These days those who are communicants in the one body shall be privileged, on that ground alone, to be admitted to communion in the other body, without individual tests. This is known as intercommunion. Thus, true 'ecumenism' is only possible on a one-to-one basis; individuals with individuals.

The history of ecumenical movement may be dated from AD 1517-1948. The modern ecumenical movement started from the Edinburgh Missionary Conference of 1910, though this itself owed much to the earlier movements, which prepared the way. The success of the conference led to the establishment of the International Missionary Council; the Universal Christian Council on life and work (1925); the World Conference on Faith and Order (1927). The initiative of the movements between 1910 and 1927 came mainly from Western Protestantism. It was, however, greatly reinforced in 1920 by an Encyclical letter from the Patriarch of Constantinople appealing to all the churches of Christ, for "closer intercourse and mutual co-operation" (Ekpunobi, 2001, p. 26; Nmah, 2012).

It is interesting to note that the original idea in the formation of the World Council of Churches (WCC) was to form a Christian Confederation that would resist opposition. The Holy Synod of the Church of Constantinople invited other churches, among them Anglican and the Roman Catholic Church to form a league of Churches. The league of churches was to be like the league of nations which was then in its formative states. When the organization was eventually formed in 1948, it was called World Council of Churches, not "World League of Churches".

Factors responsible for the failure to attain organic union include era of Western political expansion, interaction action and reaction, emigration and immigration, revolution, industrial upheaval and so on. There are three types of Christian responses to other religions. These are: exclusivism, pluralism and inclusivism. The exclusivists insist that there is no salvation in any other belief system. When such people accept to enter into dialogue, their hidden agenda is the conversion of unbelievers to their own brand of Christianity. Exclusivism is supported by Christo-centric theology. The great theologian, Karl Barth, led the way in this theological perspective. He argued that all religions and all cultures are judged in the light of Christ. Barth maintained that "other religions are just unbelief" (Ekpunobi, 2001, p. 93). But Jesus is Christ of universal love.

Whereas exclusivism maintains that salvation is only through Christ, pluralism argues that all religions are equal and valid paths to salvation. All religions manage to get to God in their peculiar ways. Inclusivism holds that Christ is the standard though people of other religions can be saved. It is a compromise between exclusivism and pluralism. Karl Rahner, a Jesuit, is the leading exponent of inclusivism. He explains that "God desires salvation for everyone".

In Nigeria, according to Enwerem (1995), there was at the outset a lack of national unity among the Christian Churches in 1960s, although there was some interaction among them. There were three blocs of Christianity namely the Christian Council of Nigeria (CCN) in the South, the Christian movement in the North and the United Roman Catholic Episcopal Conference each of which meets at least once a year and spoke with one voice. About 1965, there was a move to unify Anglican, Methodist, and other Churches, but the civil war and other factors disrupted the aim. There are co-operative enterprises undertaken by the $\mathrm{CCN}$. This includes education. The joint action of Anglicans and Methodists saw the establishment of Women Colleges, Emmanuel Theological College, and Trinity Union Theological College in Ibadan and Umuahia respectively (Nmah, 2012).

Trinity Theological College and Queen Elizabeth hospital Umuahia were jointly established by Anglicans, 
Methodists and Presbyterians. The CCN engages also in literature and publication. A living example is the Daystar Press Ibadan and the Nigerian Christian, a monthly magazine publication.

On social sphere, the CCN has four main functions such as (a) stimulation of stewardship and social services; (b) assistance and guidance in organization and promotion of projects, for which funds are sought and received from donor agencies, (c) execution of material resources programme, especially in the area of custom clearing and forwarding of shipments to church's related hospitals, health institutions and similar organizations, and (d) representation and participation in national and international conferences. The CCN institute has been involved in the Islam in African Project now Project for Christian Muslim Relations in Africa (PROCMURA).

Today we have in Nigeria the Christian Association of Nigeria (CAN), whose aims include fellowship of churches, working together to promote the glory of God as association of Christian Churches with distinct identity, recognizable Church structures and a system of worship of one God in the trinity which make Christ the center of all their pastoral life and works among others. The current terrorism, corruption and political crises in Nigeria have heightened the place of Christian union and political nationalism. These churches represent a rich diversity of cultural backgrounds and traditions, worship in dozens of languages, and live under every kind of political system. Yet they are all committed to close collaboration in Christian witness and service.

The CAN has also its challenges such as lack of authoritative president, the blocs protecting their interest, political bigotry, corruption, hatred, envy, and similar vices. In order to overcome these challenges, it will be imperative to have a kind of "federation of churches" whose membership would be voluntary in their official capacity rather than blocs, and each church retaining its freedom and independence in the management of its internal affairs, but all recognizing one another as sisters with equal rights, and co-operation in general enterprises. Such co-operation will include the spread of the gospel at home and abroad, the defense of the faith against terrorism, and infidelity, the elevation of the poor and down trodden or the neglected classes of the society.

\section{Conclusion and Recommendations}

A coat of many doctrinal controversies: an x-ray of Nigerian Christian spirituality appraised some salient doctrinal differences among Christians in Nigeria that have hampered unity among different denominations in the 21st century. This is a reminiscence of Trinitarian controversy (AD 195), which lingered on till 325 or of what happened in 640-1652 where Christianity was subjected to Roman, Vandal and Byzantine rule, each group imposing its unique ideas on the people. The church was divided among Catholic, Donatist and Monophysite parties (Boer, 1976, Falk, 1997). It was a millennium of darkness. By 697; the Arabs occupied North Africa, which came after the Byzantines lost control of the seas and could not intervene. As in Egypt, the Christians were subjected to economic pressure, which they could not support.

In addition to the suppression of the church by the Arabs and the flight of many Christians to Europe, the rapid disappearance of the church in North Africa was no doubt also due to its not having thoroughly taken root in Berber population. This resulted in part because the scriptures had not been translated, and the liturgy had not been prepared, in the language of the people. Furthermore, the Donatist Church, which ministered to the Berber population, was suppressed by the imperial edict. The church was divided because of the theological controversies and was not enthusiastically supported by the people. Thus it disappeared, leaving hardly a true of its existence in the region during five centuries.

In respect of the modern Christians in Nigeria, there is the need for the churches to be united more than ever in the face of global Islamic terrorists' attacks such as the Boko Haram, Al Shabab, A1 Qaeda, Taliban and other tervorist groups. This is coupled with the emergence of ethnic militias such as the O'dua People's Congress (OPC), the ljaw Youth Congress, the Movement for the survival of Ogoni People (MOSOP), the Movement for the Actualization of Biafran Republic (MASSOB), and so on. Ethnic and religious nationalism rather than patriotism has also led to the call for what some Nigerians called, "Sovereign national conference" or "National Conference" (Nmah, 2012).

In order for Nigerian Christians to counter the insurgents and protect their faith, they have to be united, strong and courageous in the face of teething situation. The unity should not be limited to a particular denomination alone, but interdenominational in nature lest the Christians regret as it happened to North African Christians. There should be exchange of pulpits and programmes among the Christians. At times these programmes may be conducted by way of workshops, seminars, conferences and in seminaries. There should also be genuine love and filial piety among the denominations. The trinity, the apostles' creed or Nicene creed, the Eucharist, the baptism, the Christmas, the Good Friday, the Easter, the Epiphany of our Lord, lent, the Pentecost and prayer, all christo-centric, can serve as a meeting point among the Nigerian Christians irrespective of their coat of many doctrinal colours. From beginning to end the Bible is filled with 
numerous teachings on such topics as God, creation, the human race, sin, Christ, salvation, the Holy Spirit, the church and the end times. The sum total of all of these teachings is known as Christian doctrine. There are also individual doctrines, and denominational doctrines.

The Bible insists that these teachings must be passed on from generation to generation (Proverbs 7:2; Psalm 78:5), and warns against false doctrine taught by false teachers (1 Tim. 1:3). While it is beyond doubt that the Bible urges us to anchor our faith with correct teaching, it is not enough simply to confess certain facts about God. To know God is both to affirm certain propositions about him and to have a relationship with him, a relationship that centers on our trust, our obedience and our worship.

The Bible makes it clear that it is not enough to master biblical information intellectually, but that the divine word must penetrate the hearts of the learners. When it does, they will learn to trust in the Lord, become wise, and shape their lives according to the divine instruction. Those who educate are to walk alongside others to model, encourage, train and guide learners into lives that glorify God and exhibit wisdom.

\section{References}

Agunwa, T.V.C. (2008). Denominationalism in Christianity: the bane of the gospel message. Journal of Arts and Social Science, Volume 2, 88-103.

Boer, H.R. (1976). A short history of the early church. Ibadan: Daystar.

Cross, F.L. \& Livingstone, E.A. (Eds.). (1997). The Oxford dictionary of the Christian Church. Texas: Oxford University.

Douglas, J.D. et al (Eds.). (1980). The new Bible Dictionary. Leicester: Inter Varsity.

Enwerem, I. M. (1995). A dangerous awakening: the politicization of religion in Nigeria. Ibadan: African Book Builders.

Falk, P. (1997). The growth of the church in Africa. Bukuru: African Christian Textbooks (ACTS).

Henderson, E.F. (1910). Select historical documents of the middle ages. London: George Bell \& Sons.

Kalu, O.U. (1978). Divided people of God. New York: NOK.

Martin, L. (1993). Websters new encyclopedia dictionary. New York: Black Dog \& Leventha.

Matthew, I.(2005). What are indulgences? In a Catholic life retrieved on 20th July, 2013 from http//www.ACatholic life.bloyspot.com.

Miravalle, M.I. (1993). Mary: coredemptrix, mediatrix and advocate. Santa Barbara: Queenship.

Nmah, P.E. (2002). The seven words on the cross: The good Friday message for sober reflection in the contemporary Nigerian society. Umuahia: Lintdsons Co-operative Publications.

Nmah, P.E. (2012). Basic and applied Christian ethics: An African perspective. Gucks Systems INT'L.

Quarcoopome, T.N.O. (1985). The synoptic gospel. Ibadan: African University Press.

Shelley, B.L. (2008). Church history in plain language. Nashville: Thomas Nelson. 